\title{
RESPONSES OF CORTICAL EXTRASTRIATE AREA 21a NEURONS SPECIALIZED IN MOTION DETECTION
}

\author{
Received March 25, 2014
}

According to a generally accepted concept, the stationary structure of the receptive field of a visually sensitive central neuron predetermines transformation and central processing of the incoming information, including that related to moving visual stimuli. We found, however, that a small group of visually sensitive neurons of the cat extrastriate cortical area 21a does not fit this statement and exhibits no responses to stationary visual stimuli while responding vigorously to moving images. The results of our experiments showed that response patterns of these neurons to moving stimuli display high degrees of diversification and processing of incoming visual information. We suppose that these neurons may be strictly specialized in the detection and central processing of visual information necessary for perception of moving images.

Keywords: extrastriate cortical area 21 a, visually sensitive neurons, receptive field, moving stimuli.

\section{INTRODUCTION}

Neurophysiological mechanisms underlying central information processing in the visually sensitive cortical areas, including the extrastriate area $21 \mathrm{a}$, still constitute a fundamental problem in neuroscience. Since the pioneering studies of Hartline $[1,2]$ and Hubel and Wiesel [3-5], the "receptive field" (RF) concept of a single visually sensitive neuron has become the most important substrate for interpretation of the mechanisms governing perception of stationary and moving visual images. In their classic studies of visually evoked responses of neurons in the cat and monkey striate cortex, Hubel and Wiesel $[4,5]$ classified cells on the basis of their response patterns to presentation of stationary visual stimuli. Thus, according to the proposed concept, the stationary structure of the receptive field, as a rule, predetermines transformation and central processing of incoming visual information concerning the moving visual stimuli. A number of subsequent studies have, in

\footnotetext{
${ }^{1}$ Laboratory of Sensory Physiology, Institute of Applied Problems of Physics, National Academy of Sciences of Armenia, Yerevan, Armenia.

2 Department of Neuroscience, Cell Biology, and Physiology, Wright State University, Dayton, USA.

Correspondence should be addressed to

D. K. Khachvankian (e-mail: khachvankyan@mail.ru),

H. R. Aslanian (e-mail: hayk_aslanyan@yahoo.com),

A. L. Ghazaryan (e-mail: ana13am@yahoo.com),

B. A. Harutiunian-Kozak (e-mail: rnigagik@gmail.com),

J. A. Kozak (e-mail: ashotkozak@aim.com).
}

general, confirmed this concept [6-9]. At the same time, the experiments carried out by our group showed that certain discrepancies in this approach are evident [10-12]. In our studies of information processing related to moving visual images, we observed only a weak correlation (in some cases, even almost complete absence of correlation) between the stationary structure of the neuronal RF and response patterns of the cell to presentation of moving stimuli. In this report, we describe further observations concerning a relatively small group of neurons in the cat extrastriate area 21a, which did not react to stationary flashing light spots positioned in their RFs (hand-held stimuli) but responded strongly to the moving visual stimuli. In earlier studies, such neurons were reported to be found in the ventral geniculate nucleus (VGN) [13] and striate cortex [14]. We investigated in detail the qualitative and quantitative characteristics of the activity of such neurons with the aim to elucidate the function of this group of neurons in central processing of visual information with special attention to processing of the moving image perception.

\section{METHODS}

The methods used were described in detail in our earlier publications $[11,15]$. The cats were initially anaesthetized with $\alpha$-chloralose (60 $\mathrm{mg} / \mathrm{kg}$, i.m.). Tracheotomy and cannulation of the femoral artery 
were performed. Throughout the experiment, anaesthesia was maintained by additional chloralose doses given i.v. (10-20 mg/kg per hour). The animal's head was fixed in a stereotaxic apparatus (HorsleyClarke, modified for visual research). A piece of the bone $(6 \times 10 \mathrm{~mm})$ was removed from the skull above the posterior suprasylvian gyrus. The opening was covered with $3 \%$ agar in $0.9 \% \mathrm{NaCl}$ solution to prevent brain pulsations and to provide visual control of electrode penetrations into the cortical area $21 \mathrm{a}$. The animal was immobilized by i.m. injection of $7 \mathrm{mg} / \mathrm{kg}$ Ditilin (diiodide dicholine ester of succinic acid). Artificial respiration was administered at $19 \mathrm{~min}^{-1}$, with stroke volume $20 \mathrm{ml} / \mathrm{kg}$ body mass. The body temperature was kept constant at $38^{\circ} \mathrm{C}$ with a heating pad. The pupils were dilated by topical application of $0.1 \%$ atropine solution, and the corneas were protected from drying with zero-power contact lenses. Nictitating membranes were retracted by instilling Neo-Synephrine (1\%) into the conjunctival sac. The arterial blood pressure was continuously monitored and stabilized at 90-100 mm Hg. The ECG and EEG were continuously monitored throughout the experiment. In some cases, a standard procedure of labeling (electrocoagulation) of the successful recording points and perfusion of the animal with a fixative ( $10 \%$ formalin solution) was carried out. The recording sites were identified after examination of $50-\mu \mathrm{m}$-thick histological sections of the brain.

Extracellular recordings of single-unit activity were provided by tungsten microelectrodes coated with vinyl varnish leaving a $1-3 \mu \mathrm{m}$ bare tip (impedance 10-15 M $\Omega$ ). Action potentials (APs) were conventionally amplified, triggered, and passed to a digital analyzer for on-line analysis and data storage using a poststimulus time histogram (PSTH) mode; 16 realizations for each stimulus type were averaged. The RF borders for each visually responsive cell were defined by presentation of hand-held stimuli and plotted on a perimeter screen. Positions of the optic disc and area centralis (AC) were also plotted on the screen, and the RF position within the visual field was referenced to the AC location [16, 17]. For initial characterization, the RF borders of a visually sensitive single cell were outlined in detail by presentation of stationary flashing light spots $(0.5-2.0 \mathrm{deg})$ positioned consecutively across the hand-plotted RF area. Then, moving visual stimuli (spots, bars, edges, and slits of different sizes and contrasts) were presented with the speed of motion $20 \mathrm{deg} / \mathrm{sec}$. The direction sensitivity index (DSI) for each neuron was calculated according to the formula DSI $=\left(1-\mathrm{R}_{\mathrm{npr}} / \mathrm{R}_{\mathrm{pr}}\right) \cdot 100$ [8], where $\mathrm{R}_{\mathrm{npr}}$ and $\mathrm{R}_{\mathrm{pr}}$ are responses to the non-preferred and preferred directions, respectively. Neurons with DSI $=$ $=100$ were classified as unidirectional, with DSI $=$ $=20$ to 99 as asymmetric directional, and with DSI $=0$ to 19 as bidirectional units. The contrast specificity index (CSI) was calculated for light (L), and dark (D) stimuli according to the contrast specificity $=(\Sigma \mathrm{L} / \Sigma \mathrm{L}+$ $+\Sigma \mathrm{D}) \times 100$ [17], where indices of 100 , about 50 , and 0 characterized units responding to light only, with approximately equal response intensities to light and dark, and responding to dark only, respectively.

The values of contrast for the light and dark stimuli against the background were kept constant with the contrast defined as $\left(\mathrm{L}_{\max }-\mathrm{L}_{\min }\right) /\left(\mathrm{L}_{\max }+\right.$ $\left.+\mathrm{L}_{\min }\right)$, where $\mathrm{L}_{\max }$ and $\mathrm{L}_{\min }$ are the maximum and minimum luminances, respectively. The bright stimuli were $15 \mathrm{~lx}$ against a $2 \mathrm{~lx}$ background, and the dark stimuli were, conversely, $2 \mathrm{~lx}$ luminance against a 15 lx background.

\section{RESULTS}

A total of 152 visually sensitive neurons was examined within the extrastriate area 21 a of the cat cortex. As a first step, careful determination of the RF borders and of its position within the visual coordinate system was performed for each cell using a hand-held visual stimulus. Afterwards, the response patterns of neurons were investigated by applying stationary and moving visual stimuli of constant contrast. The RF borders and the stationary functional RF structure were outlined by stationary flashing light spots $(0.5-2 \mathrm{deg})$ positioned consequently in the test zones over the entire RF surface. A great majority of the examined neurons (144 of 152) showed clearcut responses to both stationary flashing light spots and moving visual stimuli. A small group of neurons (8 of 152) demonstrated, however, a complete absence of response to stationary flashing light spots but generated intense AP bursts to presentation of moving visual stimuli. Moreover, these neurons with the absence of the stationary RF structure were able to discriminate contrasts, sizes, and contours of visual stimuli and direction of their motion. In this report, results of detailed investigation of the response profiles of such neurons to moving visual stimuli are described with the aim to elucidate their possible role and significance in central processing of visual information. 


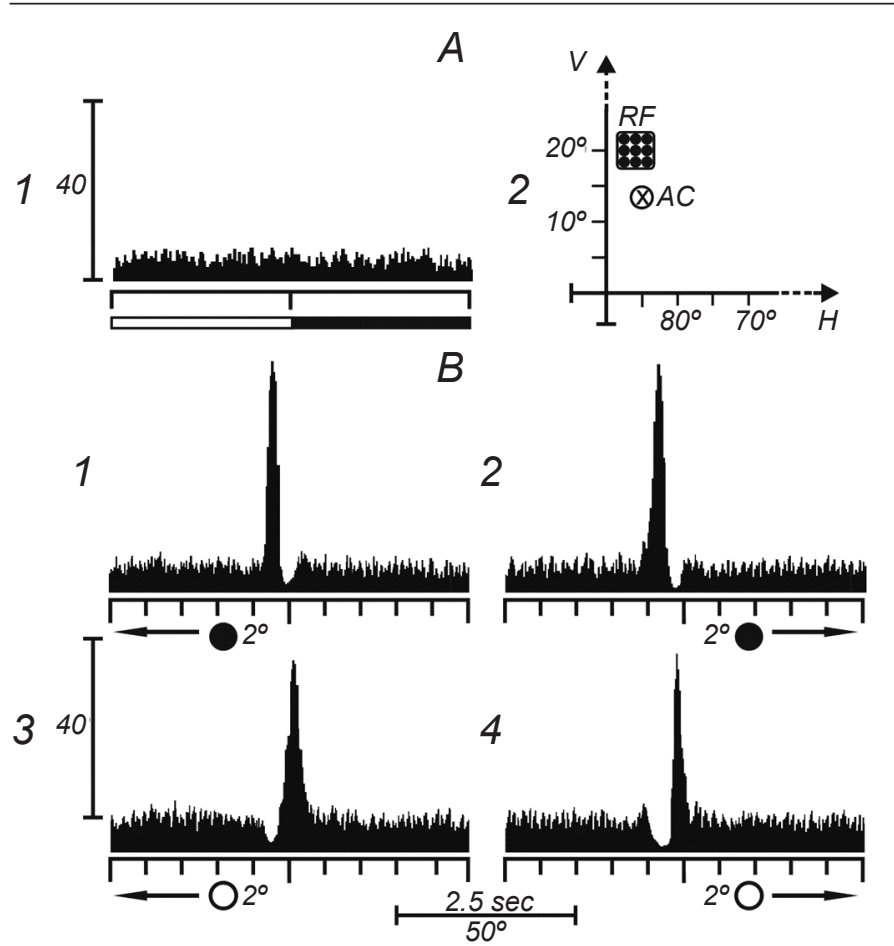

F i g. 1. Response patterns of an area 21a neuron to presentation of stationary and moving visual stimuli. A, 1) Absence of responses of the neuron to the stationary flashing light spot $(2 \mathrm{deg})$ positioned in the receptive field center (outlined by hand-held stimuli). A, 2) Hand-plotted position of the neuronal RF within the visual coordinate system; black dots indicate consecutive positions (test zones) of the flashing spot across the RF. B, 1, 2) PSTHs of the responses of the same neuron to the dark spot ( $2 \mathrm{deg})$ across the RF horizontal axes moving leftward (1) and rightward (2). B, 3, 4) PSTHs of the neuron responses to the movement of the bright spot (2 deg) in two opposite directions. Arrows indicate the direction moving of the visual stimulus. Explanations are the same for the following figures.

Р и с. 1. Патерни відповідей нейрона зони 21 а на пред'явлення стаціонарних та рухомих зорових стимулів.

In Fig. 1, the response patterns of a neuron of this type are shown. As can be seen, there were no reactions to a stationary flashing spot $(2 \mathrm{deg})$ positioned sequentially across the hand-plotted RF (Fig. 1A, 2, black dots); only the PSTH of the activity obtained by stimulation of the RF central position is presented. By contrast, when dark and bright spots $(2 \mathrm{deg})$ moved along the horizontal axis of the hand-plotted RF, bursts of neuronal discharges were elicited (Fig. 1B, 1-4). The moving dark spot evoked nondirectional responses of the cell at two opposite movement directions (Fig. $1 \mathrm{~B}, 1,2)$, with a weak inhibitory phase after the AP bursts. The bright spot movement also evoked a nondirectional response pattern, but with a strong inhibitory phase before the cell discharges (Fig. 1B, $3,4)$. When analyzing the response profiles described above, one may suggest that the stationary RF of this neuron should be characterized as a homogeneous "off" RF. As is shown in Fig. 1A, 1, this is, however, not the case when a stationary flashing spot is presented. Furthermore, quantitative measurements of the numbers of APs indicated that this neuron is, probably, capable of discriminating the contrast of

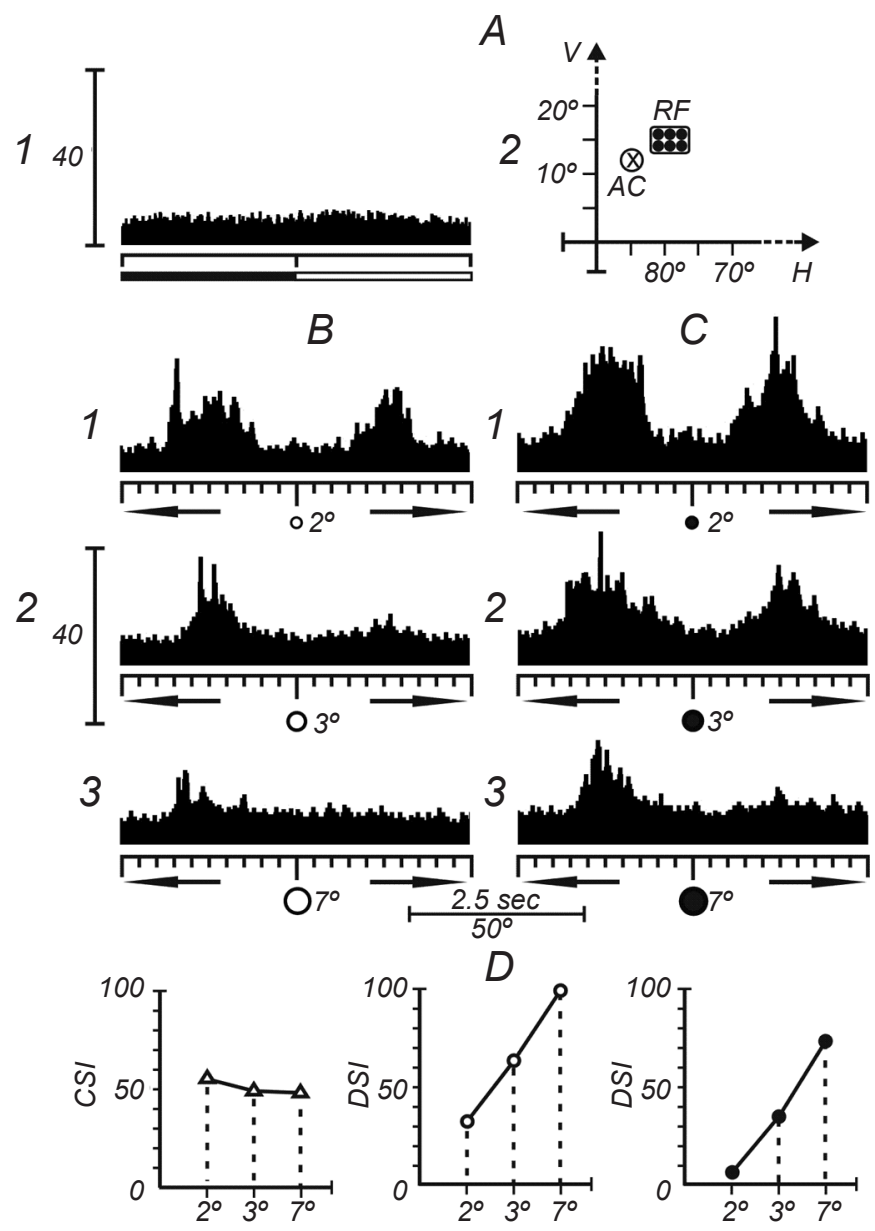

F i g. 2. Response patterns of a neuron insensitive to presentation of a stationary flashing light spot but highly sensitive to moving visual stimuli. A, 1) Lack of neuronal responses to a stationary visual stimulus. A, 2) Hand-plotted position of the neuronal RF within the visual coordinate system. B, 1-3) PSTH of the neuronal responses to presentation of moving bright spots of different sizes indicated under the histograms. C, 1-3) PSTH of the responses of the same neuron to the movement of dark spots of different sizes. D, 1-3) Plots of the contrast specificity index (CSI) measured for different sizes of applied moving stimuli (1), and the direction sensitivity index (DSI) for bright (2) and dark (3) moving stimuli. Explanations for the following figures are the same.

P и с. 2. Патерни відповідей нейрона, не чутливого до пред'явлення стаціонарної світлової блимаючої плями, але високочутливого до візуальних рухомих стимулів. 
the applied stimulus. The bright stimulus is preferable considering the greater number of APs compared to that related to the dark stimulus (CSI $=58)$.

In Fig. 2, the response patterns of another neuron of this group are illustrated. As is seen in Fig. 2A, 1, the neuron did not respond to the stationary flashing bright spot (2 deg). At the same time, moving 2-deg spots of two opposite contrasts elicited intense discharges of the neuron at two opposite motion directions (Fig. 2B, 1, C, 1). When the size of moving spots was increased to $3 \mathrm{deg}$, nondirectional responses of the neuron to a dark moving stimulus were elicited (Fig. 2C, 2), while a bright spot elicited clear-cut directionally asymmetric responses $(\mathrm{DSI}=65.5)$, with the preferred direction from the right to the left (Fig. 2B, 2). A further increase in the size of the stimulus (7 deg) led to a clear-cut direction-selective response pattern of the neuron. As is seen in Fig. 2B, 3, both bright spot and dark spot motions (Fig. 2C, 3) elicited directionally asymmetric responses of the

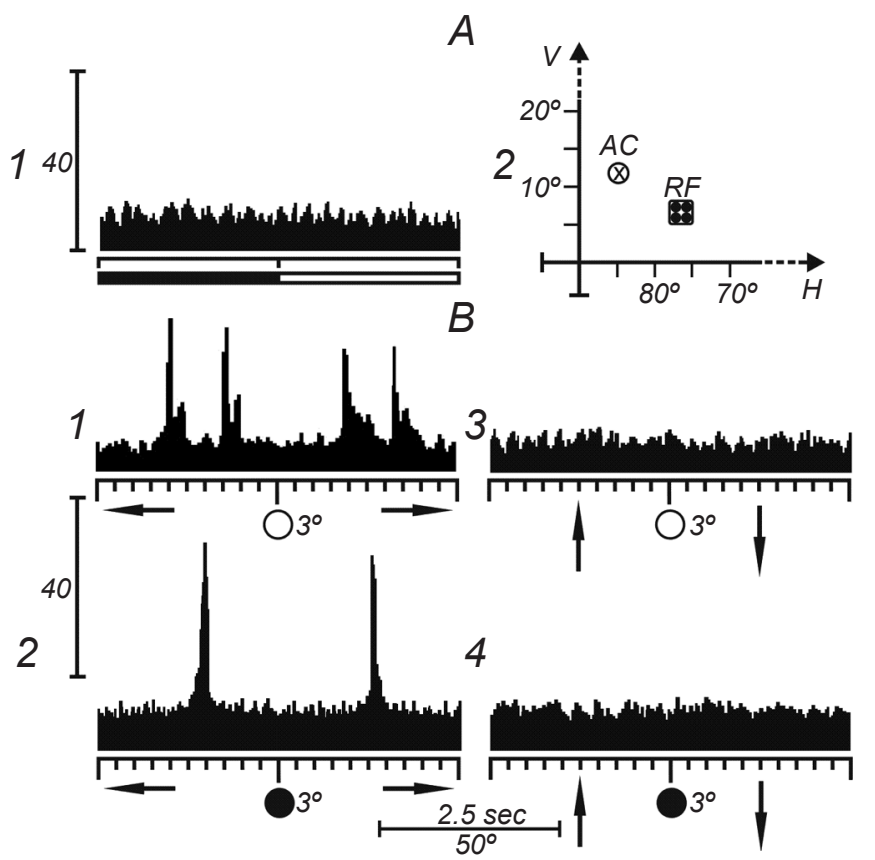

F i g. 3. Response patterns of a neuron to the movement of as visual stimulus in the horizontal and vertical directions. A, 1) PSTH of neuronal activity at presentation of a stationary flashing spot. A, 2) The position of the hand-plotted RF within the visual coordinate system. B, 1, 2) PSTHs of neuronal responses to the movement of bright (1) and dark (2) spots along the RF horizontal axis. B, 3, 4) PSTHs of the responses to the movement of bright (3) and dark (4) spots along the RF vertical axis.

P и с. 3. Патерни відповідей нейрона на рухи візуального стимулу в горизонтальному та вертикальному напрямках. neuron with the same rightward preferred direction (DSI $=100$ for the bright spot and 74.3 for the dark spot; Fig. 2D and D, 3). Thus, the neuron clearly reveals certain abilities to discriminate the contrasts and motion directions of the applied visual stimuli.

Furthermore, two of eight neurons investigated showed significant qualitative and quantitative differences between the discharge patterns in relation to opposite contrasts and also in relation to the movement orientation of applied visual stimuli. Figure 3 illustrates the response patterns of one of these neurons to stationary and moving visual stimuli. The neuron responded by a bimodal discharge pattern to a 3-deg bright spot moving in two opposite directions, which means that there are two spatially distinct discharge centers in the RF separated from each other by an about 16-deg angular distance (Fig. 3B, 1). A dark moving spot of the same dimension ( $3 \mathrm{deg})$ evoked monomodal responses of the neuron (Fig. 3B, 2). The same neuron generated no responses when the orientation of stimulus movement changed from the horizontal to the vertical one (Fig. 3B, 3, 4). In other words, both stimuli (bright and dark) became ineffective in this case. Thus, the neuron not only discriminated the contrast of the applied stimulus, demonstrating qualitatively and quantitatively different pattern properties at two opposite contrasts, but was also able to discriminate orientations of the stimulus motion within the visual space. Again, it was difficult to propose a conceptual interpretation of the observed phenomenon because we could not characterize the stationary RF organization.

For the next neuron, the response patterns to moving visual stimuli of different sizes were tested. As can be seen in Fig. 4A, 1, this neuron generated no spike responses to the flashing light spot positioned in the RF test zones (Fig. 4A, 2, black dots). However, a bright rectangle $(2 \mathrm{deg} \times 4 \mathrm{deg})$ moving along the horizontal axis of the RF of this unit (determined by presentation of hand-held stimuli) elicited AP bursts when the stimulus entered and left the RF; strong inhibition of background spiking of the neuron was observed at the movement along the RF horizontal axis in both rightward and leftward directions (Fig. 4B, 1). The movement of the same rectangle at an oblique orientation (135 deg visual angle) evoked almost the same response pattern, namely inhibition of background discharges when crossing the RF (Fig. 4B, 2). The opposite contrast of the same stimulus (dark rectangle) induced excitatory responses of the neuron 


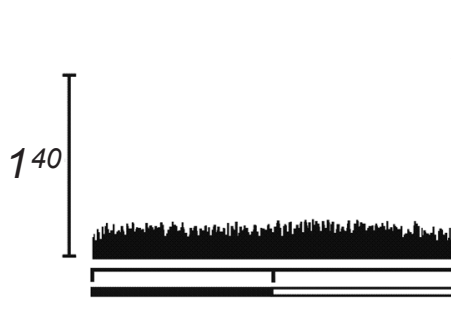

$A$

$B$

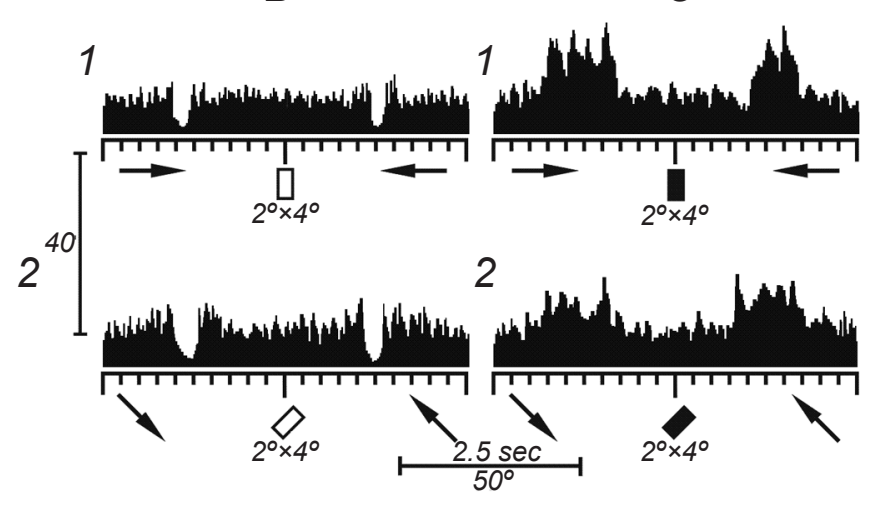

$D$
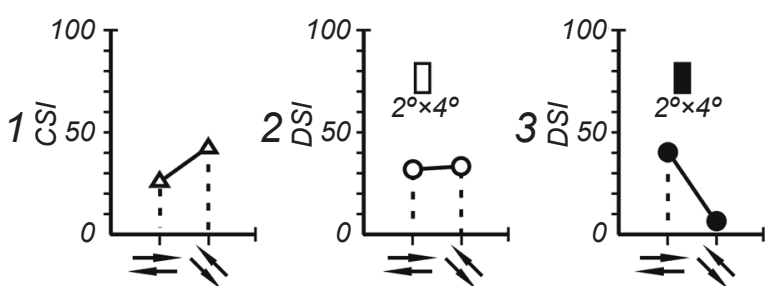

F i g. 4. Response patterns of a neuron to presentation of moving bright and dark rectangles. A, 1) Lack of responses to a stationary flashing light spot. A, 2) Position of the hand-plotted RF within the visual coordinate system. B, 1, 2) PSTHs of neuronal responses to a (2 deg $\times 4$ deg) bright rectangle moving in the horizontal (1) and oblique (135 deg) directions (2) across the RF. C, 1, 2) PSTHs of the responses of the same neuron to the horizontal (1) and oblique (2) movements of the dark (2 deg $\times 4 \mathrm{deg})$ rectangle. D, 1-3) Contrast specificity index (CSI) (1) and direction sensitivity index (DSI) for presentation of bright (2) and dark (3) rectangles moving in the horizontal and oblique directions.

Р и с. 4. Патерни відповідей нейрона на пред'явлення яскравих та темних рухомих прямокутників.

at both horizontal and $135 \mathrm{deg}$-orientation motions (Fig. 4C, 1, 2).

An unexpected result was observed when the size of the rectangles was changed. The same neuron responded by excitation with AP bursts to the movement of a $6 \mathrm{deg} \times 11 \mathrm{deg}$ bright rectangle along the horizontal axis across the RF (Fig. 5A, 1) and to the oblique $(135 \mathrm{deg})$ movement of such stimulus through the RF (Fig. 5A, 2). An excitatory effect of the stimulus movement along the horizontal axis of

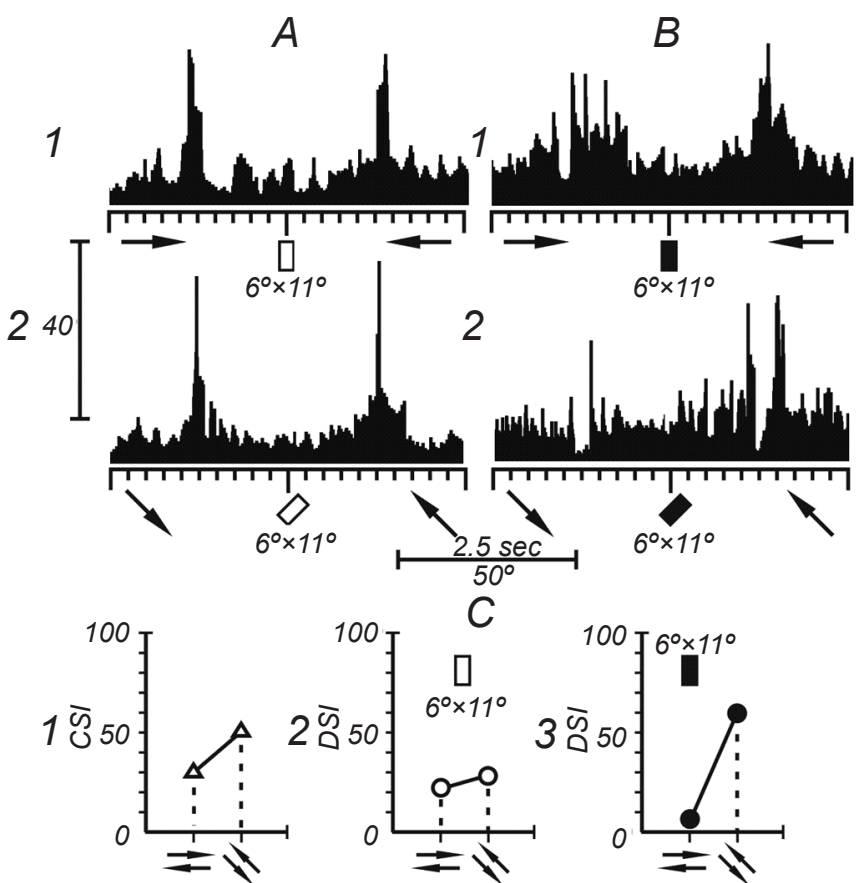

F i g. 5. Response patterns of the same neuron, as in Fig. 4, to the movements of bright and dark rectangles of a greater dimension. A, $1,2)$ PSTHs of neuronal responses to the horizontal $(1)$ and oblique $(135 \mathrm{deg})(2)$ movements of a bright rectangle $(6 \mathrm{deg} \times 11 \mathrm{deg})$. $\mathrm{B}, 1,2)$ PSTHs of the responses to horizontal (1) and oblique (2) movements of a dark rectangle $(6 \mathrm{deg} \times 11 \mathrm{deg})$. C, 1-3) Contrast specificity index (1) and direction sensitivity index measured for the movements of $6 \mathrm{deg} \times 11 \mathrm{deg}$ bright (2) and dark (3) rectangles in the horizontal and a 135 deg directions.

Р и с. 5. Патерни відповідей того самого нейрона, що й на рис. 4, на рухи яскравих та темних прямокутників більшого розміру.

the RF was observed when the opposite contrast of the stimulus (dark) was used (Fig. 5B, 1). A change in the motion orientation to $135 \mathrm{deg}$ of the visual coordinate system, on the other hand, evoked clear-cut inhibition of background neuronal activity upon crossing the RF central region, while excitation was observed when the stimulus entered and left RF borders (Fig. 5B, 2). These data point to a high level of discrimination of incoming visual information related to the size and orientation of the moving visual stimuli across the RF, even though the examined neuron did not demonstrate a conventional stationary RF organization.

In summary, the presented data show that there is a relatively small population of neurons (about $5 \%$ ) in the area $21 \mathrm{a}$ that do not respond to stationary visual stimuli but reveal a strong ability to detect moving images and to discriminate their contrasts, sizes, directions, and orientations of motion of such visual images. It is likely that these neurons participate in 
central processing of visual information by acting as highly specialized motion detectors.

\section{DISCUSSION}

It has already been reported by Fries and Albus [19] that a stationary map of the RF of a visually sensitive neuron in the cat striate cortex is insufficient to explain the response characteristics of this unit to moving stimuli. Dynamic properties of the neuron are much more complicated. In an earlier communication [10], we also emphasized that there is a group of dark-sensitive neurons in the cat lateral suprasylvian cortical area, which showed extremely low sensitivity to stationary flashing spots but could be effectively triggered by moving visual stimuli. The results of the experiments described above agree with such observations and, importantly, indicate that a relatively small group of neurons in the extrastriate area $21 \mathrm{a}$ is also insensitive to stationary flashing light spots (thus, in fact, having no stationary RF) but react vigorously and with diversified patterns of activity to presentation of moving visual stimuli.

As a working hypothesis, we suggest that activation of neighboring neurons brought up by the moving stimuli crossing the RF surrounding may exert certain influences on the neuronal activity under investigation. Earlier, it was well established by different research groups that excitation of the RF surrounding area exerts significant effects on the neuronal response patterns by modulating the activity profile $[15,20$ 22]. Thus, it seems probable that a neuron, being insensitive to the stationary visual stimuli, probably undergoes transient changes in its excitability when moving visual stimuli activate the neighboring groups of neurons by crossing their RFs within the visual space before entering the RF of the examened.

Our results show that there are significant quantitative and qualitative differences in the intensity of evoked spiking of the described neurons depending on the size and contrast of the applied visual stimuli. Thus, a high degree of information diversification does exist in this case. These results allow us to suggest that relatively small groups of neurons in the central visual pathways, while being unresponsive to stationary visual stimuli, are strictly specialized in motion detection. Probably, this feature is provided by modulatory influences of the adjacent activated neurons having RFs overlapping the RF of the neuron under investigation. It is likely that such interactions are transient events occurring within the time interval of moving of the visual image. Evidently, interaction within a group of neurons can provide a more precise and efficient estimation and processing of incoming visual information than the activity of a single isolated neuron might be expected to. Further investigations are needed to elucidate the nature and neurophysiological mechanisms underlying such specialized temporary influences in central processing of visual information.

The study was carried out in accordance with the statements of the Council Directive regarding the protection of animals used for experimental and other scientific purposes $(86 / 609 /$ EEC, 1986, Strasbourg) and respective regulations of the Ethics Committee at the Institute of Applied Problems of Physics, National Academy of Sciences of Armenia, Yerevan, Armenia.

The authors of this study, D. K. Khachvankian, H. R. Aslanian, B. A. Harutiunian-Kozak, A. L. Ghazaryan and J. A. Kozak, confirm that the research and publication of the results were not associated with any conflicts regarding commercial or financial relations, relations with organizations and/or individuals who may have been related to the study, and interrelations of coauthors of the article.

\section{Д. К. Хачванкян ${ }^{1}$, Г. Р. Асланян ${ }^{1}$, Б. А. Арутюнян-Козак ${ }^{I}$, А. Л. Газарян ${ }^{1}$ Ю. А. Козак ${ }^{2}$}

\section{ВІДПОВІДІ КОРТИКАЛЬНИХ НЕЙРОНІВ ЕКСТРАСТРІАТНОЇ ЗОНИ 21А, СПЕЦІАЛІЗОВАНИХ НА ДЕТЕКЦІЇ РУХІВ}

\author{
${ }^{1}$ Інститут прикладних проблем фізики НАН Вірменії, \\ Среван (Республіка Вірменія). \\ 2 Державний університет Райт, Дейтон (США).
}

P е 3 ю м е

Згідно із загальноприйнятою концепцією, стаціонарна структура рецептивного поля візуочутливого нейрона визначає специфіку трансформації та центральної обробки зорової інформації, що надходить, включно з інформацією про рухливі візуальні стимули. Ми, проте, виявили, що властивості невеликої групи візуочутливих нейронів у кортикальній екстрастріатній зоні 21а не узгоджуються 3 цим положенням; вони не генерують відповідей на пред'явлення стаціонарних зорових стимулів, але в той же час інтенсивно відповідають на пред'явлення рухомих зображень. Як показали результати наших експериментів, патерни відповідей даних нейронів на дію рухомих стимулів демонструють високі рівні диверсифікації та обробки візуальної інформації, що надходить. Ми вважаємо, що ці нейрони можуть бути високоспеціалізованими щодо детекції та центрального процесінгу зорової інформації, необхідної для перцепції рухомих зображень. 


\section{REFERENCES}

1. H. K. Hartline, "The response of single optic nerve fibers of the vertebrate eye to illumination of the retina," $\mathrm{Am} . \mathrm{J}$. Physiol., 121, No. 2, 400-415 (1938).

2. H. K. Hartline, "The receptive field of the optic nerve fibers," Am. J. Physiol., 130, No. 3, 690-699 (1940).

3. D. H. Hubel and T. N. Wiesel, "Receptive fields of single neurons in the cat's striate cortex," J. Physiol., 148, No. 3, 574-591 (1959).

4. D. H. Hubel and T. N. Wiesel, "Receptive fields, binocular interaction and functional architecture in the cat's visual cortex," J. Physiol., 160, No. 1, 106-154 (1962).

5. D. H. Hubel and T. N. Wiesel, "Receptive fields and functional architecture in two nonstriate visual areas (18 and 19) of cat," J. Physiol., 28, No. 2, 229-289 (1965).

6. P. O. Bishop, J. S. Coombs, and G. H. Henry, "Responses to visual contours: spatio-temporal aspects of excitation in the receptive fields of simple striate neurons," J. Physiol., 219 , No. 3, 625-657 (1971).

7. K. Albus, "The detection of movement direction and effects of contrast reversal in the cat's striate cortex,"Vision Res., 20, No. 4, 293-298 (1980).

8. K. Toyama, M. Kimura, and K. Tanaka, "Organization of cat visual cortex as investigated by cross-correlation technique," J. Neurophysiol., 46, No. 2, 191-201 (1981).

9. R. C. Reid and J. M. Alonso, "Specificity of monosynaptic connections from thalamus to visual cortex," Nature, 378, No. 6554, 281-284 (1995).

10. B. A. Harutiunian-Kozak, R. L., Djavadian, and A. V. Melkumian, "Responses of neurons in cat's lateral suprasylvian area to moving light and dark stimuli," Vision Res., 24, No. 3, 189-195 (1984).

11. B. A. Harutiunian-Kozak, D. K. Khachvankian, G. G. Grigoryan, et al., "Responses of neurons in cortical area 21 a to moving visual stimuli," Inform. Technol. Manage., 2, No. 1, 42-51 (2008).

12. H. R. Aslanian, B. A. Harutiunian-Kozak, D. K. Khachvankian, et al., "Motion detector neurons in area 21a of the cat cortex," Nat. Acad. Sci. RA, Electron. J. Nat. Sci., 22, No. 1, 145-149 (2014).

13. P. D. Spear, D. C. Smith, and L. L. Williams, "Visual receptive field properties of single neurons in cat's ventral lateral geniculate nucleus," J. Neurophysiol., 40, No. 2, 390-409 (1977).

14. D. Debanne, D. Shultz, and J. Fregnac, “Activity dependent regulation of "on" and "off" responses in cat visual cortical receptive fields," J. Physiol., 508, No. 2, 523-548 (1998).

15. B. A. Harutiunian-Kozak, A. B. Sharanbekian, A. L. Kazarian, et al., "Spatial summation processes in the receptive fields of visually driven neurons of the cat's cortical area 21a," Arch. Ital. Biol., 144, No. 1, 127-144 (2006).

16. P. O. Bishop, W. Kozak, and G. J. Vakkur, "Some quantitative aspects of the cat's eye: axis and plane reference, visual field co-ordinates and optics," J. Physiol., 163, No. 3, 466-502 (1962).

17. R. Fernald and R. Chase, "An improved method for plotting retinal landmarks and focusing the eyes," Vision Res., 11, No. 1, 95-96 (1971).

18. P. H. Schiller, B. L. Finley, and S. F. Volman, "Quantitative studies of single-cell properties in monkey striate cortex. I. Spatiotemporal organization of receptive fields," $J$. Neurophysiol., 39, No. 6, 1288-1319 (1976).

19. W. Fries and K. Albus, "Static and dynamic properties of receptive fields of some simple striate cells in the cat's striate cortex," Vision Res., 16, No. 5, 563-566 (1976).

20. J. T. McIllwain, "Receptive fields of optic tract axons and lateral geniculate cells: peripheral extent and barbiturate sensitivity," J. Neurophysiol., 27, No. 6, 1154-1173 (1964).

21. G. Rizzolatti and R. Camarda, "Inhibition of visual responses of single units in the cat visual area of the lateral suprasylvian gyrus (Clare-Bishop area) by the introduction of a second visual stimulus," Brain Res., 88, No. 2, 357-361 (1975).

22. A. M. Sillito, "Inhibitory mechanisms influencing complex cells orientation selectivity and their modification at high resting discharge levels," J. Physiol., 289, No. 1, 33-53 (1979). 